\title{
3. SITE 383: DRILLING ABOVE THE J-ANOMALY RIDGE IN THE SOHM ABYSSAL PLAIN
}

\author{
The Shipboard Scientific Party ${ }^{1}$
}

\section{SITE DATA}

Position: $39^{\circ} 14.88 \mathrm{~N}: 53^{\circ} 21.18^{\prime} \mathrm{W}$

Water Depth (PDR, sea level): 5283 meters

Water Depth (PDR, rig floor): 5293 meters

Bottom Felt at (rig floor): 5277 meters

Penetration: 120.3 meters

Number of Holes: 1

Number of Cores: 2

Total Length Cored: 19.1 meters

Total Core Recovered: 4.9 meters

Core Recovery: 26 per cent

Oldest Sediment Cored: Coarse sand

Bottom at: 63.3 meters

Age: Pleistocene

Nature of Basement: Not reached

Date Occupied: $2228 \mathrm{Z}$ hours, 10 July 1975

Date Departed: 1022Z hours, 12 July 1975

Time on Site: 1 day, 11 hours, 54 minutes

Principal Results: Site 383 was drilled a total of 120.3 meters into the Sohm Abyssal Plain above the buried $J$. Anomaly Ridge (Figures 1, 2). Deteriorating hole conditions and the risk of losing the bottom-hole assembly in the caving sands forced abandonment. The single core recovered (53.7-63.3 m) contains 4.9 meters of graded Pleistocene sand; the grading is undoubtedly an artifact produced by flushing of sand into the core barrel during a break in circulation. A second coring attempt (110.8-120.3 m), which yielded an empty core barrel, probably penetrated similar coarse sands. The coarse turbiditic sands are probably derived from the Laurentian Channel.

'Brian E. Tucholke, (Co-Chief Scientist), Lamont-Doherty Geological Observatory, Palisades, New York; Peter R. Vogt, (CoChief Scientist), Naval Research Laboratory, Washington, D.C.; Kenneth R. Demars, University of Rhode Island, Kingston, Rhode Island (now at: University of Delaware, Newark, Delaware); Jon S. Galehouse, San Francisco State University, San Francisco, California; Robert L. Houghton, Woods Hole Oceanographic Institution, Woods Hole, Massachusetts (now at: University of Alberta, Edmonton, Alberta, Canada); Ansis Kaneps, Deep Sea Drilling Project, Scripps Institution of Oceanography, La Jolla, California; John W. Kendrick, Shell Development Company, Houston, Texas; I. N. McCave, University of East Anglia, Norwich, England; Charles L. McNulty, University of Texas, Arlington, Texas; Ivar O. Murdmaa, P. P. Shirshov Institute of Oceanology, Moscow, USSR; Hisatake Okada, Lamont-Doherty Geological Observatory, Palisades, New York (now at: Yamagata University, Yamagata, Japan); and Peter Rothe, Mineralogisch Petrografisches Institut der Universitat Heidelberg, Heidelberg, Federal Republic of Germany (now at: Geographisches Institut der Universitat Mannheim, Mannheim, Federal Republic of Germany).

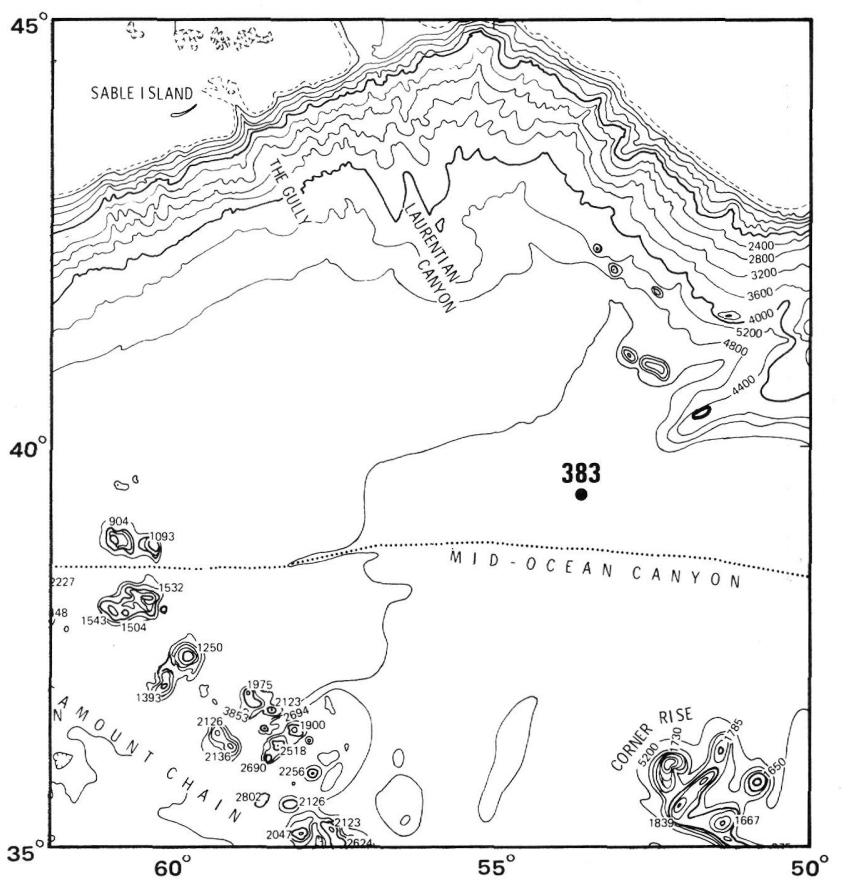

Figure 1. Bathymetric map showing location of Site 383 in Sohm Abyssal Plain. Depths in uncorrected meters.

\section{BACKGROUND AND OBJECTIVES}

As early as the 1950 's, shipborne magnetic traverses between the U.S. east coast and Europe revealed a highamplitude anomaly (locally $>1000$ gammas) striking northeast across the Sohm Abyssal Plain (Heezen et al., 1959). This " $J$-Anomaly" is also found on the African side of the Mid-Atlantic Ridge (Pitman and Talwani, 1972; Laughton and Whitmarsh, 1974; Hayes and Rabinowitz, 1975), and it therefore represents an unusual event at the ancient mid-ocean-ridge crest rather than subsequent modification of the plate. Seismic reflection profiles obtained across the anomaly on Vema 17 in 1961 and on subsequent cruises revealed a prominent basement bulge and west-facing escarpment with the same strike as the magnetic anomaly (Figures 3,4). The existence of such a structure also is indicated by regional sediment isopachs (Ewing et al., 1973).

One major objective at Site 383 was to establish the age of the $J$-Anomaly. Aeromagnetic surveying between $35^{\circ}$ and $39^{\circ} \mathrm{N}$ (Vogt et al., 1970) and shipborne data to the south (Vogt et al., 1971a) had suggested that the $J$-Anomaly was formed near the end of an interval of frequent geomagnetic reversals called the Keathley Sequence. Larson and Pitman (1972) corre- 


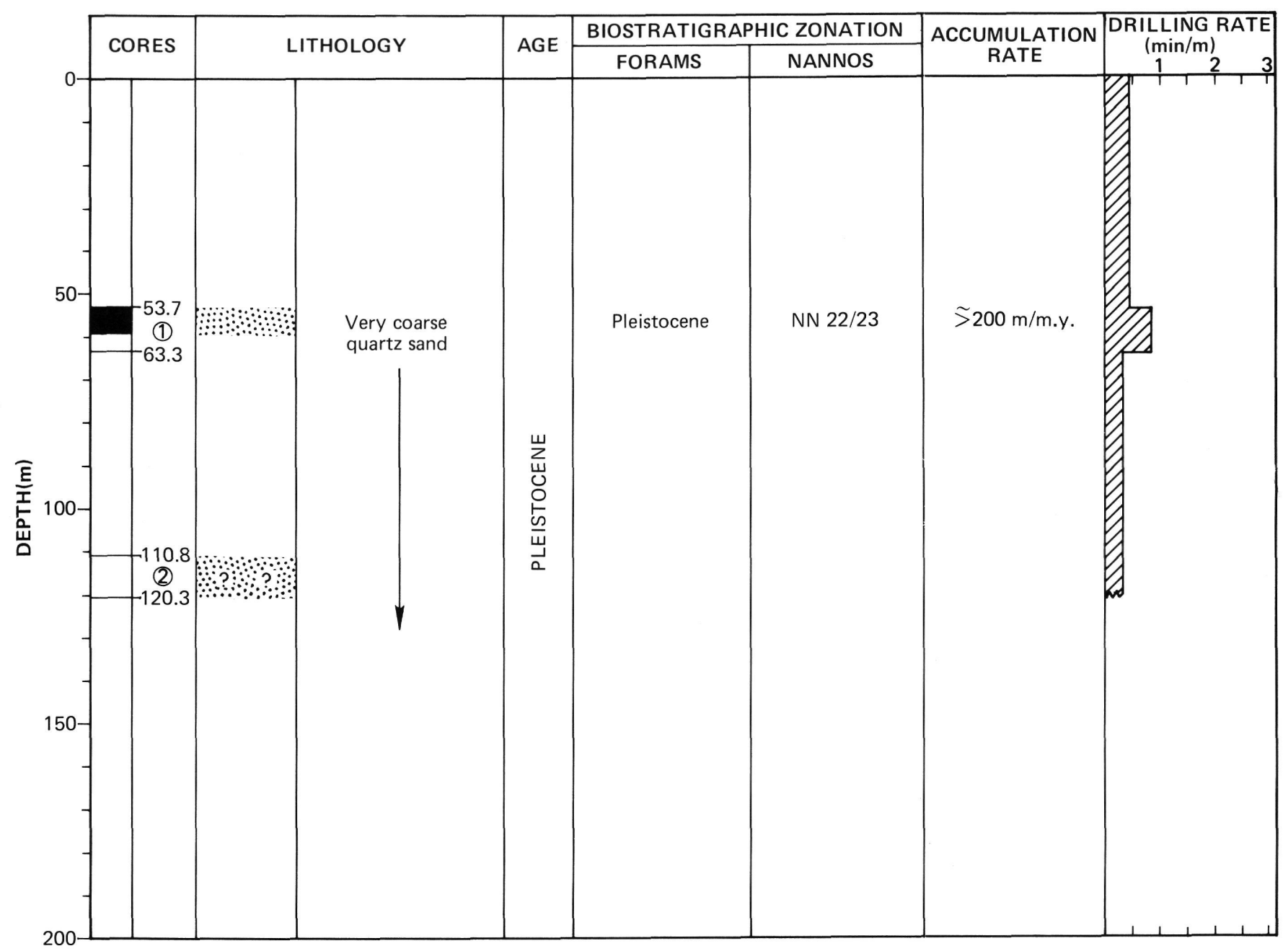

Figure 2. Graphic hole summary, Site 383.

lated these anomalies with coeval, Pacific magnetic lineations, and they introduced the term " $M$-series" for the anomalies and the reversals causing them. Contrary to the interpretation of Vogt et al. (1970; 1971a), Barrett and Keen (1976) suggested that the $J$-Anomaly is located in the middle (about anomaly $M$-14) of the Keathley Sequence ( $M$-series), rather than at its younger end.

The age of the $J$-Anomaly was first estimated to be about 135 m.y.B.P. (Vogt et al., 1971a; Pitman and Talwani, 1972). Subsequent correlation of the western Atlantic anomalies with the Phoenix, Japanese, and Hawaiian lineations in the Pacific, coupled with Pacific DSDP basement ages, suggested an age of about 110 m.y.B.P. for the younger end of the Keathley magneticreversal sequence (Larson and Pitman, 1972). This younger age implies a worldwide period of rapid spreading and broad mid-oceanic rises between the times of the $J$-Anomaly and anomaly 32 . Hays and Pitman (1973) view the great mid-Cretaceous transgression as a result of this rapid spreading and therefore as indirect confirmation for the correct dating of the Keathley Sequence ( $M$-series).

Baldwin et al. (1974) and Berggren et al. (1975) have emphasized that the dating of the $M$-anomalies is still so imprecise that the mid-Cretaceous fast spreading pulse (Larson and Pitman, 1972) may be in part an artifact of compounded age-dating uncertainties. Ages that could range anywhere from middle Aptian (112 m.y.B.P. on the van Hinte (1976) time scale) to lower Valanginian (129 m.y.B.P.) have been determined at three Pacific drill sites located near the younger end of the $M$-series (Larson and Hilde, 1975). Crust of $J$-Anomaly age has not been dated previously but should be about 5 m.y. younger than whatever correct average age is assigned to the above Pacific sites. If the $J$-Anomaly were located in the middle of the $M$-series (Barrett and Keen, 1976), the basement age should be much greater, about 125-130 m.y.B.P. on the van Hinte (1976) time scale. A complicating factor is that the $J$-Anomaly is associated with a prominent basement ridge; sediment accumulation on the ridge crest may have begun significantly later than the time immediately following crustal formation, or subsequent igneous activity may have occurred. In either instance borehole ages on the ridge would err on the low side.

A second major objective was to determine the nature of the igneous basement and its possible relationship to the high-amplitude " $J$-Anomaly." A geomagnetic explanation for this feature (for example, anoma- 



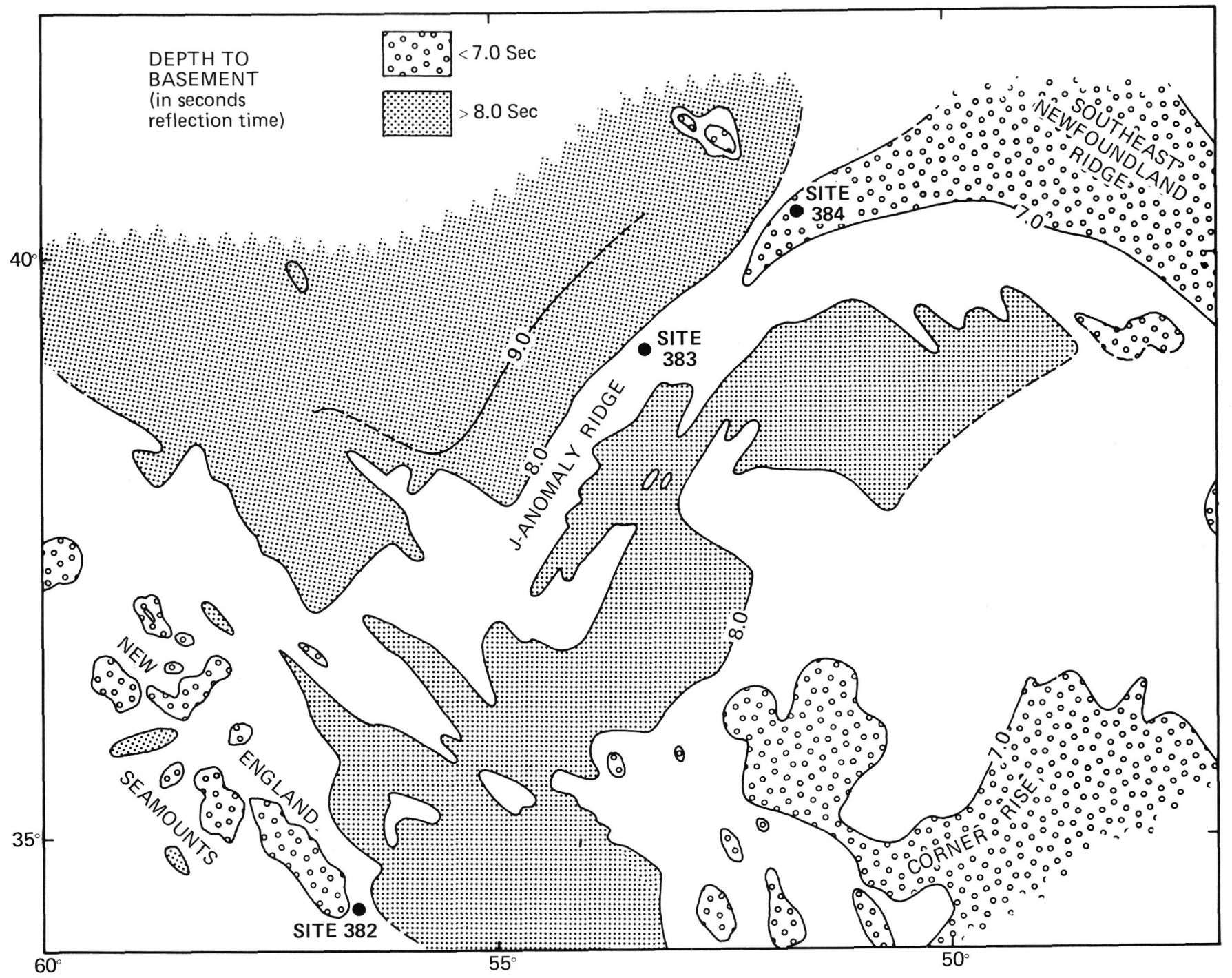

Figure 4. Depth to acoustic basement (in seconds reflection time below sea level) in the vicinity of the J-Anomaly Ridge.

lous paleo-intensity of the dipole field) is ruled out because a similar feature is not observed in the Pacific at the young end of the $M$-series (Keathley sequence). This leaves essentially three possibilities, or some combination thereof. First, the $J$-Anomaly may reflect a thickened pillow-basalt layer of otherwise normal composition and magnetization. This explanation is favored by the observation that the $J$-Anomaly typically is associated with a complex basement ridge or escarpment. The basement rises gently toward the west beneath Site 383 and then drops abruptly from sub-bottom depths of about 400 to 500 meters at the ridge crest to depths of 1000 to 1500 meters; the basement then continues to deepen gradually toward the continental margin. Although it is an impressive basement structure, the $J$-Anomaly Ridge and escarpment are insufficient to account for the 800 gamma and greater magnetic anomaly purely by their topographic effects (i.e., simply as a thickening of the $\sim 500$-m-thick pillow lavas that are presumed to produce the reversal lineations). As a comparative example, topographic relief of this magnitude is present along the crest of the present
Mid-Atlantic Ridge without any comparable magnetic anomaly amplitudes.

A second possibility is that beneath a normal pillowlava layer there exists a large, anomalous mass of gabbro, chromite, or serpentinite, any of which if sufficiently thick could account for the amplitude of the anomaly. In the case of serpentinite, the magnetization would be induced and would not be a record of the paleomagnetic field. Third, the pillow layer itself may be anomalous in composition or magnetization. Around certain hot spots (especially the Juan de Fuca and Galapagos ridges) sea-floor-spreading magnetic lineations of about two to three times normal amplitude are found. The high amplitudes seem to reflect anomalously high $\mathrm{Fe}$ and $\mathrm{Ti}$ concentrations and hence more titanomagnetite (Vogt and Johnson, 1973). Content of $\mathrm{TiO}_{2}$ ranges up to 3 per cent and $\mathrm{FeO} \mathrm{T}$ (total $\mathrm{Fe}$ expressed as $\mathrm{FeO}$ ) up to 18 per cent. The measured intensity of thermoremanent magnetization (TRM) in these basalts is several times higher than that of normal Layer 2 tholeiites. Geochemical considerations suggest that the iron-titanium enrichment is primarily the result 
tude of the $J$-Anomaly reflects anomalous $\mathrm{Fe} / \mathrm{Ti}$ concentrations, perhaps it was related to an early Cretaceous hot spot located at the intersection of the $J$-Anomaly Ridge and the Southeast Newfoundland Ridge.

In attempting the Site 383 objective of sampling the igneous basement, penetration to levels of relatively unaltered material was desired. Analyses for major element chemistry, rare earths, $\mathrm{Sr}^{87} / \mathrm{Sr}^{86}$, and magnetic properties could then be used to evaluate the above hypotheses.

A further objective at Site 383 was to determine the history of sedimentation above the $J$-Anomaly Ridge. A thick sequence of stratified sediments (at least $300 \mathrm{~m}$ ) comprises the Sohm Abyssal Plain at the site. Numerous sandy turbidites debouching from the mouth of the Laurentian Channel and other areas along the shelf edge have probably constructed this sequence of reflectors. Drilling at Site 383 could clarify the nature of these turbidites and their time of initial deposition. Between the strongly stratified and reflective turbidite sequence and acoustic basement lies a weakly laminated layer, perhaps 100 meters thick at Site 383; determining its age and lithofacies was a primary objective. Another objective was to core a thin, reflective horizon which immediately overlies the anomalously smooth basement of the $J$-Anomaly Ridge. The reflector is clearly visible in a basement valley east of the drill site, but it approaches basement upslope and may or may not be present at the drill site. The reflector could be "Horizon $A$ " chert, a sill, a volcaniclastic layer, or another unsuspected lithofacies. The nature of the basement/sediment contact (intrusive or extrusive?) was also to be determined at Site 383 .

Finally, it has been suggested that the formation of the $J$-Anomaly (Vogt et al., 1971b) may have impeded bottom water circulation and contributed to the anaerobic conditions during the Early Cretaceous in the North Atlantic (Hollister, Ewing, et al., 1972). Careful dating of the $J$-Anomaly basement was necessary to test this hypothesis, which requires that the ridge formed before the beginning of widespread sapropel deposition (i.e., prior to Hauterivian-Barremian time, 115-126 m.y.B.P.).

\section{OPERATIONS}

By the time Glomar Challenger departed Site 382, tropical storm Amy had passed out of the area of proposed Site 383. In order to check the Challenger's seismic section against the Lynch 71 reference profile (Figure 3) we decided to intercept the Lynch track near $39^{\circ} \mathrm{N}$ and then steam northwest parallel to the track (Figure 5). At $1809 \mathrm{Z}$ the ship altered course to $330^{\circ}$ The seismic reflection record clearly showed the rather flat crest of the $J$-Anomaly Ridge, dipping gently eastward, overlain by about $0.1 \mathrm{sec}$ (two-way reflection time) of acoustically non-laminated sediment and 0.3 sec of laminated turbidites. Our seismic profile (Figure 6 ) and magnetic anomaly profile closely but not exactly resembled the Lynch data (Figure 3).

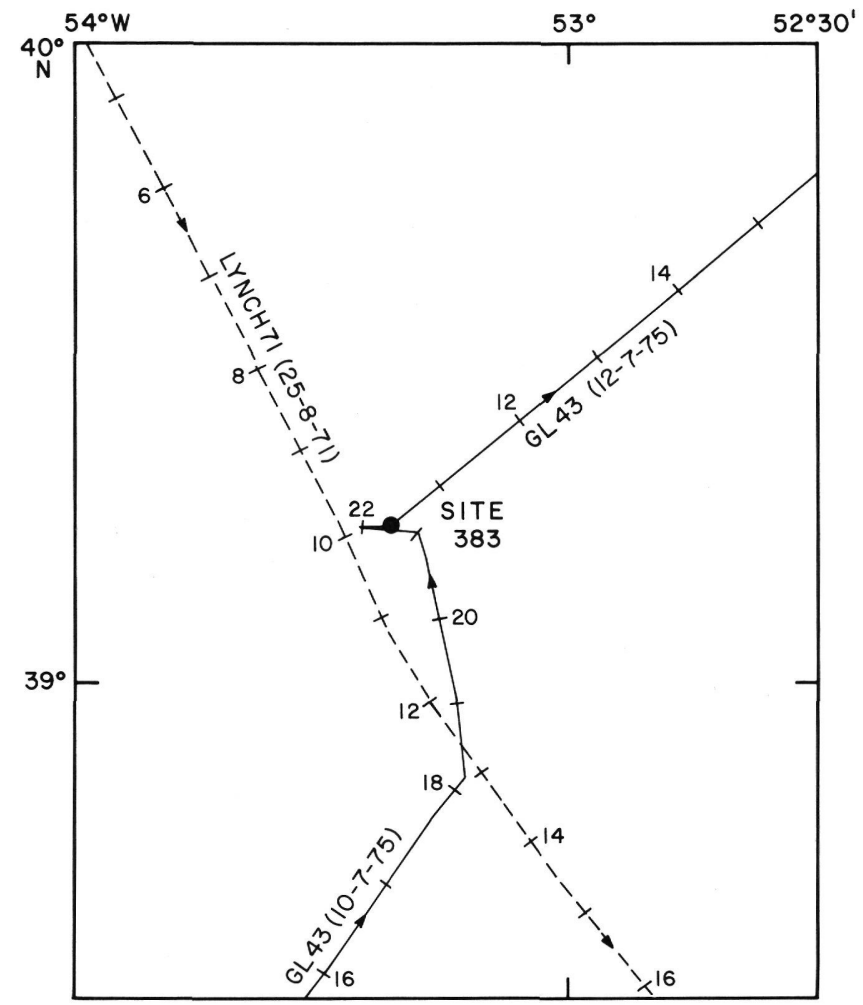

Figure 5. Location of Glomar Challenger and Lynch tracks near Site 383. Hour tracks are marked /Challenger times in GMT).

Satellite fixes showed the ship was diverging northward from the $330^{\circ}$ track of the Lynch reference profile, probably because of strong currents. At $2100 \mathrm{Z}$ course was altered to $270^{\circ}$ to bring us back toward the reference track, and at $2110 \mathrm{Z}$ speed was reduced to 6 knots to improve the seismic record. Satisfied that an acceptable coring site had been located, we reversed course to $090^{\circ}$ at $2155 \mathrm{Z}$ and dropped a pre-soaked beacon at $2228 \mathrm{Z}$. The seismic and magnetic gear were retrieved, and by $2340 \mathrm{Z}$ the positioning system was in the auto mode above the beacon. The position of Site 383 , obtained by averaging satellite fixes 472 through 486 , is $39^{\circ}, 14.88^{\prime} \mathrm{N}, 53^{\circ} 21.18^{\prime} \mathrm{W}$ (Figures 1, 5), PDR water depth, measured from sea level, was computed as 5283 meters for Matthews Area 13. The driller determined a depth of 5267 meters, corrected to sea level, and this was accepted as the official value. PDR and driller's depths thus differed by 16 meters. Had we used Matthews Area 9 (just to the north), the calculated depth would have been identical to the drill-pipe value. It is clear that in this area of high temperature/ salinity gradients near the Gulf Stream, the shifting water-mass boundaries require discretion in the use of Matthews tables.

After the drill string was run down, the heave compensator (HC) was rigged to test the system for future IPOD use and familiarize the drilling crew with its operation. During final adjustment of the heave compensator, the traveling block was lowered too quickly, and 


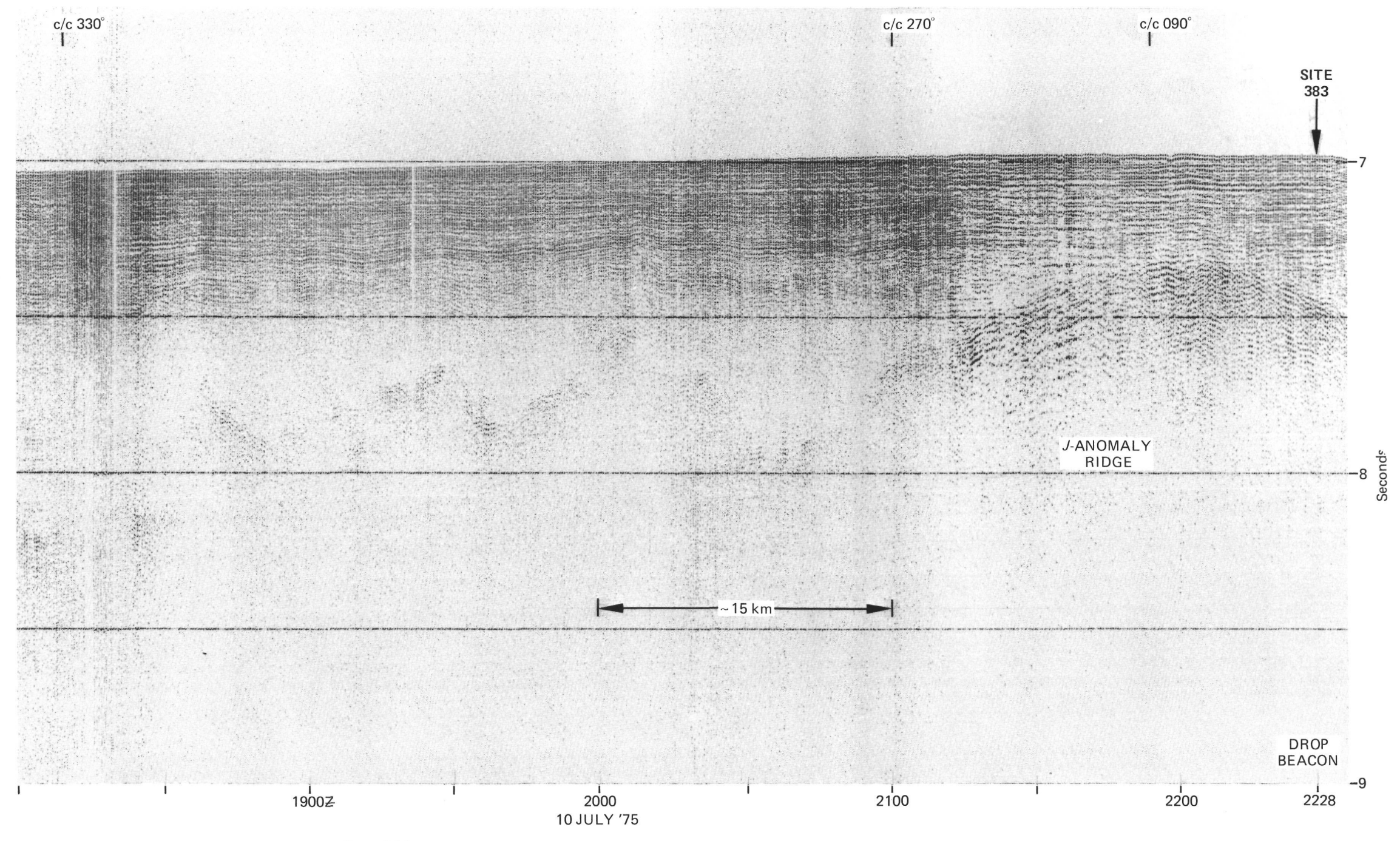

Figure 6. Challenger profiler record at Site 383. Location in Figure 5. 
of crystal fractionation at shallow levels in the upper mantle. Possibly, Fe/Ti enrichment near other hot spots (e.g., Iceland; Schilling, 1973; Vogt and Johnson, 1973) may represent in part the original anomalous mantle source chemistry. If the high magnetic amplithe $\mathrm{HC}$, a joint of drill pipe, and the pup joint below the power sub were damaged. The HC was set aside, the joints replaced, and drilling operations commenced after about 6 hours delay.

We feared that the unconsolidated turbidites of the Sohm Abyssal Plain might jeopardize hole stability at Site 383. However, we were encouraged by the fact that the turbidite sequence at this site was not so reflective as to preclude a good basement echo (Figures 3, 6 ) and that therefore enough clayey sediment might be present in the section to seal off any interbedded sands. Also encouraging was the lack of any hole stability problems in turbidites at Site 382, although Site 382 penetrated a more distal facies. Abyssal plains in a physiographic/lithologic setting similar to the Sohm Abyssal Plain had been drilled successfully off Antarctica on Leg 35.

The drill string was spudded into a "hard" bottom. We decided to core the turbidite sequence at 50-meter intervals, but encountered problems even before the first core. Near 35 meters sub-bottom a plugged annulus and partial sticking of the bit occurred; the hole was flushed with bentonite mud and drilling continued. The first core was obtained from a depth of 53.7 to 63.3 meters sub-bottom with recovery of 4.9 meters of coarse sand, up to granule size (Table 1). The coarse sand was probably "sucked" into the core barrel when circulation was cut near the bottom of the cored interval. Further drilling brought a recurrence of partial bit sticking. Additional mud flushings temporarily solved the problem, but apparently the hole walls consisted of unstable sand which constantly caved into the hole. The next core, 110.8 to 120.3 meters sub-bottom, was brought up empty at 2035 hours. The fact that it was empty indicated that sand existed in quantity at 120 meters. Because the seismic data indicated another 200 to 350 meters of similar material below, and because further penetration would put the narrower pipe above the drill collars into the hole and impose an even higher risk of getting the drill string stuck, we decided to abandon the hole. The drill string was pulled beginning at 2050 hours on 11 July, and at 0722 hours (1022Z) on 12 July Challenger was underway to Site 384.

\section{LITHOLOGIC SUMMARY}

Sediment was recovered in one core at Site 383 ( 53.7 to $63.3 \mathrm{~m}$ sub-bottom). The core contains $4.9 \mathrm{me}-$ ters of graded sand. The grading is undoubtedly artificial because the method of recovery involved cutting circulation near the bottom of the cored interval, so that the high density, sediment-laden fluid outside the drill string flushed sediment into the core barrel. Thus the core tube served as an elutriation column yielding the coarse to fine grading. Grain size ranges from fine to very fine silty sand at the top of Section 1 to coarse to very coarse sand and granules in Section 3 and 4. Section 1 contains a hard siltstone pebble $4 \times 3 \times 2$ $\mathrm{cm}$ in size. Maximum particle size in Sections 3 and 4 reaches small pebble size $(5 \mathrm{~mm})$ with 5 to 10 per cent in the granule size range.

Quartz is dominant, comprising more than 70 per cent of the sand sizes. Lithic fragments of limestone, red and gray siltstone, and quartzite are also present. In smear slides the presence of about 5 per cent heavy minerals was noted, along with minor unspecified carbonate, clay, and nannofossils.

The sands were probably emplaced by turbidity currents, although very high velocity currents were probably necessary to carry coarse material this far; the average slope is about $5 \times 10^{-4}$ between the southwest end of the Grand Banks at 5200 meters and Site 383 at 5267 meters. The source of the turbidite sands could have been either the Grand Banks or the mouth of the Laurentian Channel. The pebble found in the section probably was ice rafted.

\section{GEOCHEMISTRY}

No geochemical measurements were made at Site 383.

\section{PHYSICAL PROPERTIES}

No physical properties measurements were made at Site 383.

TABLE 1

Coring Summary, Site 383

\begin{tabular}{|c|c|c|c|c|c|c|c|c|c|c|}
\hline \multirow{2}{*}{$\frac{\text { Core }}{1}$} & \multirow{2}{*}{$\begin{array}{c}\begin{array}{c}\text { Time } \\
\text { (Day- } \\
\text { Hour) }\end{array} \\
11-1810\end{array}$} & \multicolumn{2}{|c|}{$\begin{array}{l}\text { Total Depth } \\
\text { (m) }\end{array}$} & \multicolumn{2}{|c|}{$\begin{array}{l}\text { Sub-Bottom } \\
\text { Depth } \\
\text { (m) }\end{array}$} & \multirow{2}{*}{$\begin{array}{c}\begin{array}{c}\text { Cored } \\
(\mathrm{m})\end{array} \\
9.6\end{array}$} & \multirow{2}{*}{$\begin{array}{c}\begin{array}{c}\text { Recov- } \\
\text { ered } \\
(\mathrm{m})\end{array} \\
4.90\end{array}$} & \multirow{2}{*}{$\begin{array}{c}\begin{array}{c}\text { Recov- } \\
\text { ered } \\
(\mathrm{m})\end{array} \\
51\end{array}$} & \multirow{2}{*}{ Lithology } & \multirow{2}{*}{$\frac{\text { Age }}{\text { Pleist. }}$} \\
\hline & & 5330.7 & 5340.3 & 53.7 & 63.3 & & & & & \\
\hline 2 & $11-2035$ & 5387.8 & 5397.3 & 110.8 & 120.3 & 9.5 & 0 & 0 & ? Coarse sand & \\
\hline \multicolumn{4}{|c|}{ Totals } & \multicolumn{2}{|c|}{$\begin{array}{l}\text { Total cored } \\
\text { Total recovered }\end{array}$} & 19.1 & 4.90 & & & \\
\hline \multicolumn{4}{|c|}{$\begin{array}{l}\% \text { recovery in intervals cored } \\
\% \text { recovery of depth drilled } \\
\% \text { of depth drilled which was cored }\end{array}$} & \multicolumn{2}{|l|}{$\begin{array}{l}=26 \% \\
=4 \% \\
=16 \%\end{array}$} & & & & & \\
\hline
\end{tabular}

aFrom rig floor, 10 meters above sea level. 


\section{BIOSTRATIGRAPHY}

Only one core was taken at Site 383 (at 53.7 to $6.6 \mathrm{~m}$ below the sea floor) because the loose, unconsolidated Pleistocene sands beneath the Sohm Abyssal Plain continued to collapse in the hole, presenting the danger of sticking the drill string in the hole. The core consists of a probably artifically graded sequence of silt, sand, and fine gravel.

\section{Foraminifers}

The core-catcher sample yielded a small cold-water assemblage dominated by Globorotalia inflata and small specimens of Neogloboquadrina dutertrei. These are accompanied by a few Globigerina bulloides and Neogloboquadrina pachyderma, and scarce (probably downworked) specimens of Globorotalia tumida. Benthic foraminifers are common. As at Site 382, deposition of turbidites appears to have occurred during glacial stages.

\section{Nannofossils}

Abundant and well-preserved nannofossils occur in Section 1 of the core. The occurrence of Emiliania huxleyi together with species of Gephyrocapsa indicate uppermost Pleistocene or Holocene (E. huxleyi Zone). A few reworked Cretaceous forms are also present.

\section{SEDIMENT ACCUMULATION RATES}

On the assumption that the recovered material comes from the nominally cored interval (53.7-63.3 $\mathrm{m})$, an exceedingly high rate of accumulation for the upper part of the Sohm Abyssal Plain turbidites is indicated. Since the sediments belong in the Emiliana huxleyi Zone $(<230,000$ years B.P.) the accumulation rate is in excess of $274 \mathrm{~m} / \mathrm{m} . \mathrm{y}$. While not impossible, this rate may be artificially high since there exists the distinct possibility that the recovered sediments come from some level higher in the hole. A rate of around $200 \mathrm{~m} / \mathrm{m} . \mathrm{y}$. here should not be unexpected, however, since the site lies in the central portion of the abyssal plain, and more distal turbidites at Site 382 have accumulated at a minimum rate of about $120 \mathrm{~m} / \mathrm{m}$.y. (see Chapter 2).

\section{CORRELATION OF SEISMIC PROFILE WITH DRILLING RESULTS}

The Challenger record shows a more laminated sequence of turbidites at Site 383 than does the Lynch reference profile, probably because of the higher frequency band pass $(40-160 \mathrm{~Hz})$ in the Challenger profile (Figures 3,6). The acoustically laminated sediments undoubtedly correspond to turbidites derived from the area of the Grand Banks and the Laurentian Cone. Their coarseness and poor consolidation prevented us from penetrating beyond 120 meters sub-bottom with the drill string, for fear of permanently sticking the bottom assembly in the hole. It is surprising that no clayey material was present in the single core recovered or was smeared along the bit and drill collar. However, uniform coarseness of sediment throughout most of the turbidite section might help explain the observed absence of very strong impedance contrasts (such as would be found with clay-sand interbeds) in the profiler record.

The acoustically laminated interval (turbidites) is about 0.3 seconds thick, corresponding to a true thickness of 258 to 291 meters at velocities of $1.72 \mathrm{~km} / \mathrm{sec}$ (Site 382 ) to $1.94 \mathrm{~km} / \mathrm{sec}$ (Houtz, unpublished sonobuoy data).

Sediments that are acoustically non-laminated or weakly laminated underlie this interval and overlie acoustic basement. Their acoustic character and similarity to acoustic interval 2 at Site 382 suggests that the sediments consist of rather uniform hemipelagic clays. Interval thickness of the weakly laminated sediments at Site 383 is about $0.18 \mathrm{sec}$ or 166 meters at a nominal velocity of $1.85 \mathrm{~km} / \mathrm{sec}$.

Acoustic basement at the site is unusually smooth for Layer 2 and shows a prolonged coherent echo (Figures 3,6 ). This acoustic character is common along the crest of most of the $J$-Anomaly Ridge, and it probably represents either smooth basalt flows or high-velocity sediment layers that mask igneous basement. There are subtle indications of hyperbolic echoes beneath acoustic basement in several profiles across the $J$-Anomaly Ridge, but we are uncertain of their significance in defining deeper structure.

Deep sedimentary layers abut the western side of the $J$-Anomaly Ridge, but correlative layers are notpresent on the eastern side (Figure 3). The presence of these deeper layers only on the older side of the ridge might be explained by a significant discontinuity in crustal age. However, without lithologic and age data to confirm this speculation, other mechanisms such as lower net rates of sedimentation over the ridge crest may be equally valid.

\section{SUMMARY AND CONCLUSIONS}

Site 383 penetrated 120 meters into the Sohm Abyssal Plain before deteriorating hole conditions and the risk of sticking the bottom-hole assembly forced abandonment. The single core which we recovered (53.7-63.3 m) contained coarse Quaternary sands. Continual hole caving and the recovery of an empty core barrel on the second coring attempt (110.8-120.3 m) indicate that the entire section penetrated consists predominately of unconsolidated sand. Only minor clay blebs were encountered in the first core, and a virtual absence of clay in the section is inferred. A nearly uniform section of sand would also exhibit only moderate impedance contrasts, portrayed in a seismic record as a series of parallel acoustic laminae of intermediate intensity such as we observed at this site.

The site lies near the western side of the main path of the 1929 Grand Banks turbidity current and about $50 \mathrm{~km}$ east of the main depositional area, which was along the west side of the flow (see fig. 8.14 of Heezen and Hollister, 1971). We inferred that hole stability would be less of a problem at this site than at the location originally planned for drilling within the depositional area $\left(38^{\circ} 29^{\prime} \mathrm{N}, 54^{\circ} 19^{\prime} \mathrm{W}\right)$, although it is now clear that either site would have encountered severe 
hole stability problems. Whether the coarse sand we cored at Site 383 represents part of the Grand Banks deposit probably cannot be determined from the sparse faunal assemblage and poor core recovery.

\section{REFERENCES}

Baldwin, B., Coney, P. J., and Dickinson, W. R., 1974. Dilemma of a Cretaceous time scale and rates of sea-floor spreading, Geology, v. 2, p. 267-270.

Barrett, D. L. and Keen, C. E., 1976. Mesozoic magnetic lineations, the magnetic quiet zone, and sea-floor spreading in the northwest Atlantic, J. Geophys. Res., v. 81, p. 48754884.

Berggren W. A., McKenzie, D. P., Sclater, J. G., and van Hinte, J. E., 1975. World-wide correlation of Mesozoic magnetic anomalies and its implications, Discussion, Geol. Soc. Am. Bull., v. 86, p. 267-269.

Ewing, M., Carpenter, G., Windisch, C., and Ewing, J., 1973. Sediment distribution in the oceans: The Atlantic, Geol. Soc. Am. Bull., v. 84, p. 71-88.

Hayes, D. E. and Rabinowitz, P. D., 1975. Mesozoic magnetic lineations and the magnetic quiet zone off northwest Africa, Earth Planet. Sci. Lett., v. 28, p. 105-115.

Hays, J. D. and Pitman, W. C. III, 1973. Lithospheric plate motion, sea level changes and climatic and ecological consequences, Nature, v. 246, p. 18-22.

Heezen, B. and Hollister, C., 1971. The face of the deep: New York (Oxford Univ. Press).

Heezen, B.C., Tharp, M., and Ewing, M., 1959. The floors of the oceans, I, The North Atlantic, Geol. Soc. Am., Special Paper 65, p. 1-122.
Hollister, C. D., Ewing, J. J., et al., 1972. Initial Reports of the Deep Sea Drilling Project, v. 11: Washington (U.S. Government Printing Office).

Larson, R. L. and Pitman, W. C., 1972. World-wide correlation of Mesozoic magnetic anomalies, and its implications, Geol. Soc. Am. Bull., v. 83, p. 3645-3662.

Larson, R. L. and Hilde, T. W. C., 1975. A revised time scale of magnetic reversals for the Early Cretaceous, Late Jurassic, J. Geophys. Res., v. 80, p. 2586-2594.

Laughton, A.S. and Whitmarsh, R.B., 1974. The Azores-Gibraltar plate boundary, In L. Kristjansson, (Ed.), Geodynamics of Iceland and the North Atlantic area: DordrechtHolland, (D. Reidel Publishing Company), p. 63-81.

Pitman, W. and Talwani, M., 1972. Sea-floor spreading in the North Atlantic, Geol. Soc. Am. Bull., v. 83, p. 619-645.

Schilling J. G., 1973. Iceland Mantle Plume: Geochemical study of Reykjanes Ridge, Nature, v. 242, p. 565-571.

van Hinte, J. E., 1976. A Cretaceous time scale, Am. Assoc. Petrol. Geol. Bull., v. 60, p. 498-516.

Vogt, P. R. and Johnson, G. L., 1973. Magnetic telechemistry of oceanic crust?, Nature v. 245, p. 373-375.

Vogt, P. R., Lorentzen, G. R., and Dennis, L. S., 1970. An aeromagnetic survey of the Keathley magnetic anomaly sequence between $34^{\circ} \mathrm{N}$ and $40^{\circ} \mathrm{N}$ in the western North Atlantic, Trans. Am. Geophys. Union, v. 51, p. 274.

Vogt, P.R., Anderson, C.N., and Bracey, D.R., 1971a. Mesozoic magnetic anomalies, sea-floor spreading, and geomagnetic reversals in the south-western North Atlantic., J. Geophys. Res., v. 76, p. 4796-4823.

Vogt, P.R., Johnson, G.L., Holcombe, T.L., Gilg, J.G., and Avery, O. E., $1971 \mathrm{~b}$. Episodes of sea-floor spreading recorded by the North Atlantic basement, Tectonophysics, v. 12 , p. $211-234$. 


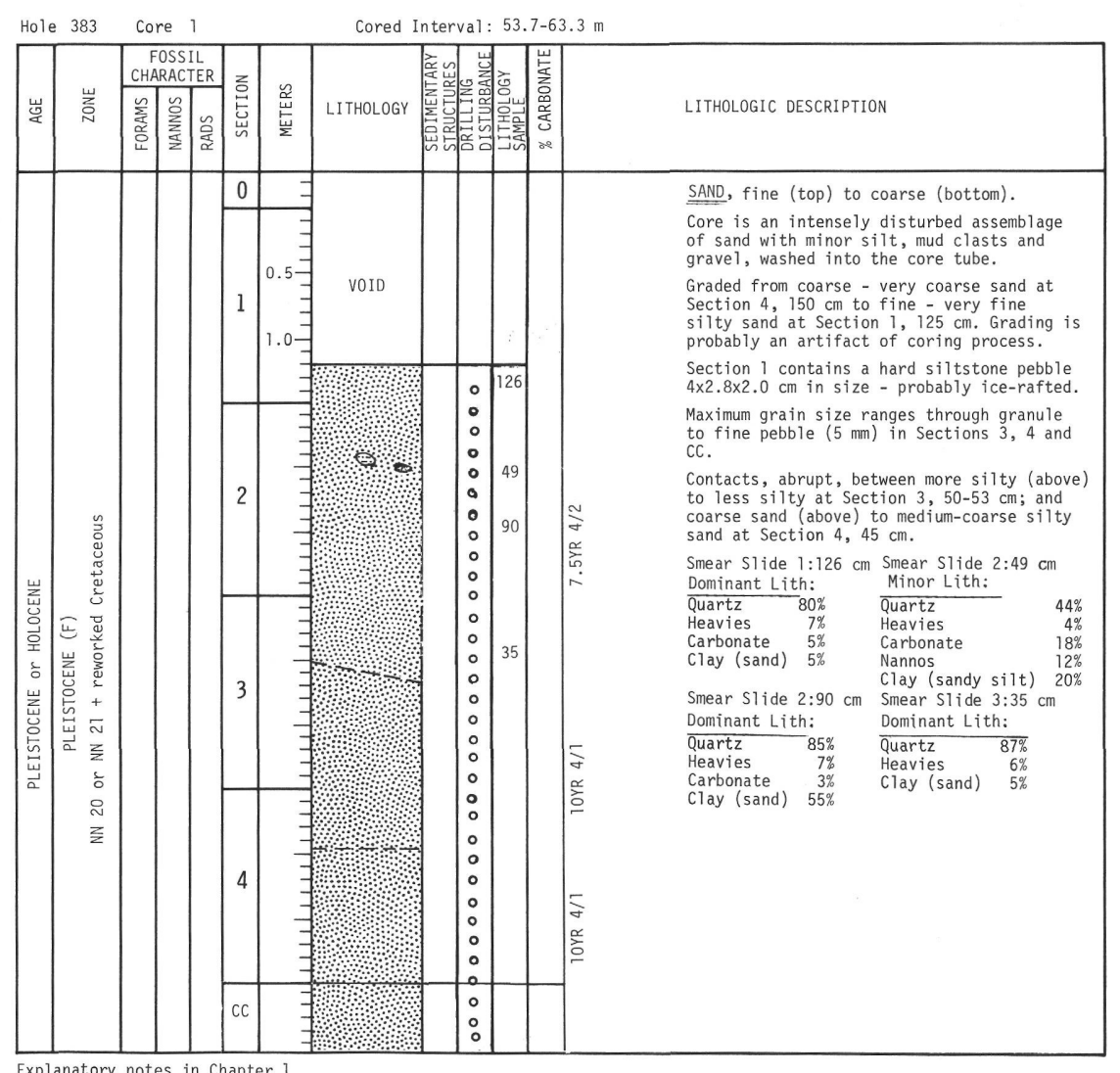

Explanatory notes in Chapter 1 


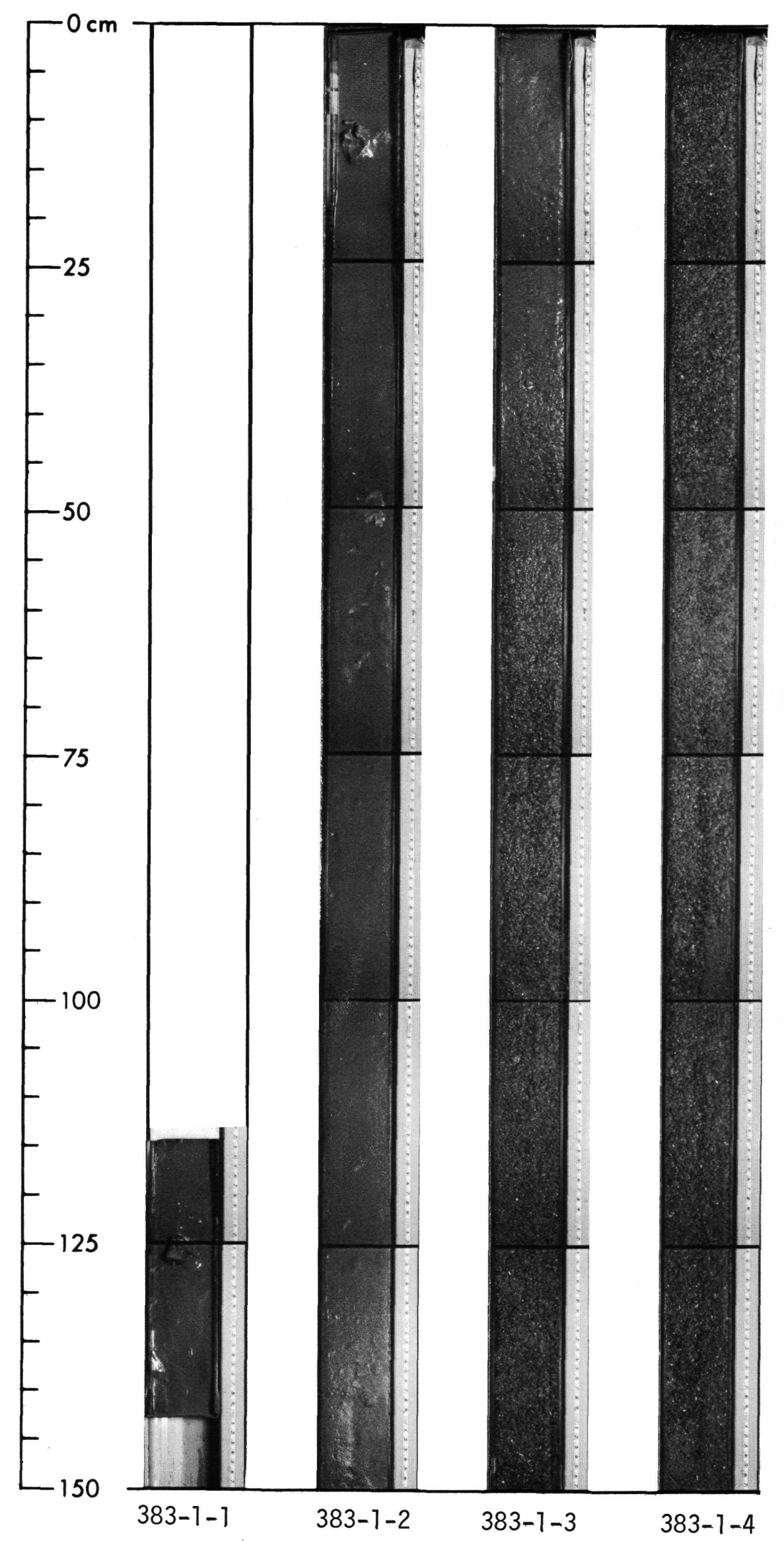

